\title{
C-Peptide in Children with Juvenile Diabetes
}

\author{
A Preliminary Report \\ J. Ludvigsson and L. G. Heding \\ Department of Paediatrics, University of Linköping, Linköping, Sweden, and Novo Research Institute, Copenhagen, Denmark
}

Summary. Serum C-peptide, insulin-binding IgG and total insulin (IRI) were determined in 96 juvenile diabetics aged 4-21 years, with onset of diabetes at the age of 1-16 years and with 2-17 years' duration of diabetes. Thirty-four patients $(35.4 \%)$ had detectable levels of C-peptide $(\geq 0.04 \mathrm{pmol} / \mathrm{ml})$. Compared to non-diabetic adults, 19 had values below the normal range, 12 showed values within the normal range $(0.18-0.63 \mathrm{pmol} / \mathrm{ml})$ and 3 rated above normal. There was a negative correlation between the fasting $\mathrm{C}$-peptide concentration and the degree of ketonuria at the onset of diabetes and a positive correlation between $\mathrm{C}$-peptide levels and the incidence of postinitial remission periods. Patients without detectable C-peptide had significantly higher levels of insulin antibodies than those who had detectable levels of C-peptide. The possibility of a relationship between the intensity of the initial treatment of diabetes and the preservation of the B-cell function is discussed, as well as the possibility of insulin antibodies being a cause of B-cell exhaustion.

Key words: Juvenile diabetes, C-peptide, remission, ketonuria, insulin antibodies, total IRI.

Insulin and C-peptide are secreted from the B-cell in equimolar amounts $[11,13]$ and $\mathrm{C}$-peptide has therefore been used as a measure of endogenous insulin secretion in insulin treated diabetics $[2,12]$. It is generally assumed that in most cases of juvenile diabetes mellitus the function of the B-cell is either drastically reduced or totally absent shortly after the onset of the disease and the initiation of insulin therapy. However, measurable amounts of $\mathrm{C}$-peptide have been found in insulin requiring maturity-onset diabetics [1] as well as in insulin-treated cases of juvenile diabetes of short duration $[7,12]$. The aim of this study was to determine C-peptide levels in a group of insulin-treated juvenile diabetics who had had diabetes for at least two years and to analyze the correlations between C-peptide and insulin antibody levels and also between C-peptide and certain clinical parameters, such as age at onset and duration of diabetes, duration of ketonuria at onset of diabetes, and the incidence of post-initial remission periods.

\section{Material and Methods}

\section{Patients}

The study comprised 96 juvenile diabetics aged 4-21 years. Their age at the onset of diabetes varied between 1 and 16 years (Table 1) and the duration of diabetes and of insulin treatment varied from 2 to 17 years (Table 2). At the time of diagnosis, 82 patients $(85.4 \%)$ had ketonuria but none became unconscious. No patient was in a post-initial remission period at the time of blood sampling for C-peptide and insulin antibodies. All the patients presented at the diabetic clinic of the paediatric department regularly 4-8 times a year. Treatment at this clinic aims at clinical well-being, absence of diabetic symptoms, normal growth and development and the best possible normalization of the metabolic state. The patients are instructed to test their urine three times a day by the Clinitest 2-drop method and to record the results in a diary shown to the doctor at each visit to the hospital. The treatment consists of insulin, a well balanced diet and regular physical exercise. As a rule, the patients were given a single daily dose of long-acting insulin (NPH or Lente) during the first few years following diagnosis, but when this regimen failed to maintain satisfactory control (this usually coincided with the first signs of 
Table 1. Age at onset of diabetes (years)

\begin{tabular}{cccccccccc}
\hline & $0-2$ & $3-6$ & $7-10$ & $11-14$ & $15-18$ & Total & Mean & SD \\
\hline Boys & 6 & 19 & 14 & 14 & 1 & 54 & 7.6 & 4.1 \\
Girls & 8 & 16 & 12 & 6 & - & 42 & 6.2 & 3.6 \\
\hline & 14 & 35 & 26 & 20 & 1 & 96 & 6.9 & 3.9 \\
\hline
\end{tabular}

Table 2. Duration of diabetes (years)

\begin{tabular}{lccccccc}
\hline & $2-5$ & $6-9$ & $10-13$ & $14-17$ & Total & Mean & SD \\
\hline Boys & 26 & 18 & 8 & 2 & 54 & 6.4 & 3.6 \\
Girls & 16 & 16 & 9 & 1 & 42 & 6.9 & 3.3 \\
\hline & 42 & 34 & 17 & 3 & 96 & 6.6 & 3.5 \\
\hline
\end{tabular}

Table 3. Insulin doses at the time of determination of C-peptide and insulin antibodies (IU/kg body weight)

\begin{tabular}{|c|c|c|c|c|c|c|c|}
\hline & $\leq 0.5$ & $0.6-1.0$ & $1.1-1.5$ & $>1.5$ & Total & Mean & SD \\
\hline Boys & 5 & 25 & 23 & 1 & 54 & 1.0 & 0.3 \\
\hline \multirow[t]{2}{*}{ Girls } & 1 & 19 & 19 & 3 & 42 & 1.1 & 0.3 \\
\hline & 6 & 44 & 42 & 4 & 96 & 1.0 & 0.3 \\
\hline
\end{tabular}

Table 4. C-peptide in 96 insulin treated juvenile diabetics $(\mathrm{pmol} / \mathrm{ml})$

\begin{tabular}{lllrlll}
\hline $\begin{array}{l}\text { No. of } \\
\text { patients }\end{array}$ & $\begin{array}{l}<0.04 \\
\text { (n.s.) }\end{array}$ & $\geqq 0.04$ & $0.04-0.17$ & $0.18-0.63$ & $>0.63$ \\
\hline Boys & 32 & 22 & 12 & 8 & 2 \\
Girls & 30 & 12 & 7 & 4 & 1 \\
\hline Total & 62 & 34 & 19 & 12 & 3 \\
\hline
\end{tabular}

Table 5. C-peptide in relation to some clinical variables

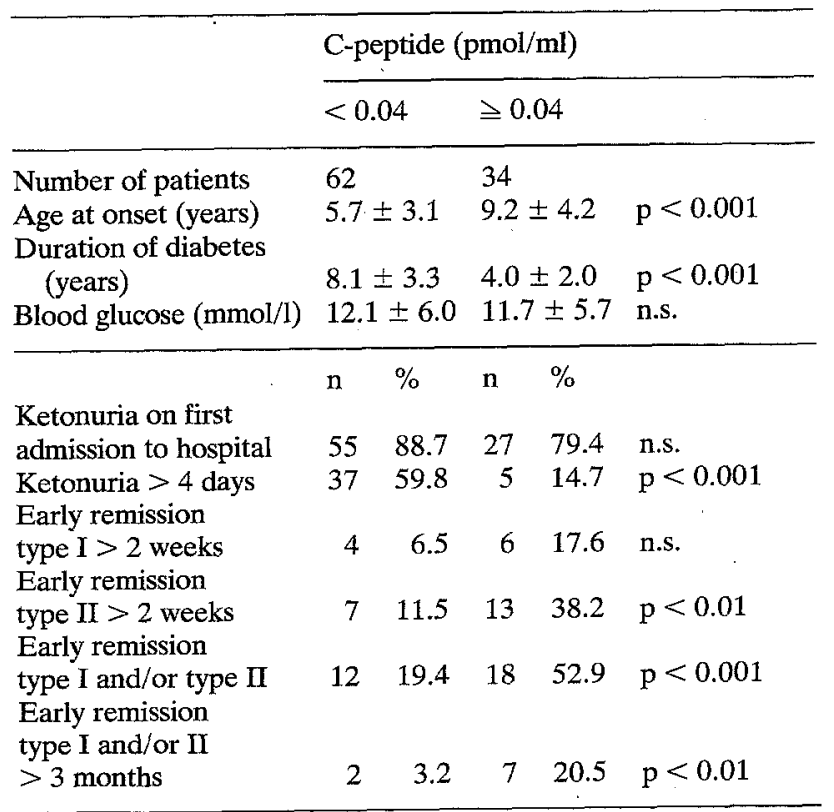

puberty), the insulin therapy was changed to twice daily injections, including the addition of a short-acting or an intermediate-acting insulin (Actrapid, Semilente). None of the patients had been treated with the MC (monocomponent) or the RI (rare immunogenic) type of insulin. At the time of the C-peptide determinations, 55 patients $(57.3 \%)$ were on single-daily insulin treatment and 41 patients $(42.7 \%)$ were receiving twice-daily injections. The insulin doses are shown in Table 3.

\section{Methods}

Blood was drawn from the fasting patients prior to their morning insulin injection. Serum was stored at $-18^{\circ} \mathrm{C}$. The binding of insulin to IgG was determined by the method of Christiansen [3] and total immunoreactive insulin, IRI, was determined after acid extraction of serum according to Heding [10]. Human C-peptide was determined by a specific radioimmunoassay in which proinsulin was removed by binding to insulin antibodies covalently coupled to Sepharose [11]. Since most of the serum contained insulin antibodies, which have been shown to bind human proinsulin, the serum was extracted at a low $\mathrm{pH}$ in the same way as described for total IRI [10] before determining C-peptide. The amount of added Sepharosecoupled insulin antibodies (binding capacity normally $1 \mathrm{mU}$ ) was in surplus of the IRI in the samples. Thus total IRI was determined prior to addition of the Sepharose-antibodies. In sera containing $>10 \mathrm{ng} / \mathrm{ml}$ of IRI the amount of Sepharose antibodies was increased as described in [11]. The recovery of C-peptide was about $90 \%$ and the results corrected accordingly. Fasting blood glucose was determined by the hexokinase method [20] in the same blood samples as those drawn for the radioimmunoassay.

\section{Clinical Data}

The clinical data were taken from the patient records. Early remission periods were classified as Type I: a period during which more than $95 \%$ of urine tests at home and/or at the hospital showed less than 1\% glycosuria and the daily insulin requirement was less than $0.5 \mathrm{IU} / \mathrm{kg}$ body weight, and as type II: same degree of diabetic control irrespective of the insulin requirement. Type I remission for over 2 weeks was recorded in 10 patients $(10.4 \%)$ (mean 131 days, range 22-450); Type II for over 2 weeks was recorded in 20 patients ( $20.8 \%$ ) (mean 73 days, range 15-255), while 65 patients $(67.7 \%)$ had no remission period. One patient $(1.0 \%)$ had over 2 weeks of a combined type I and type II remission. 


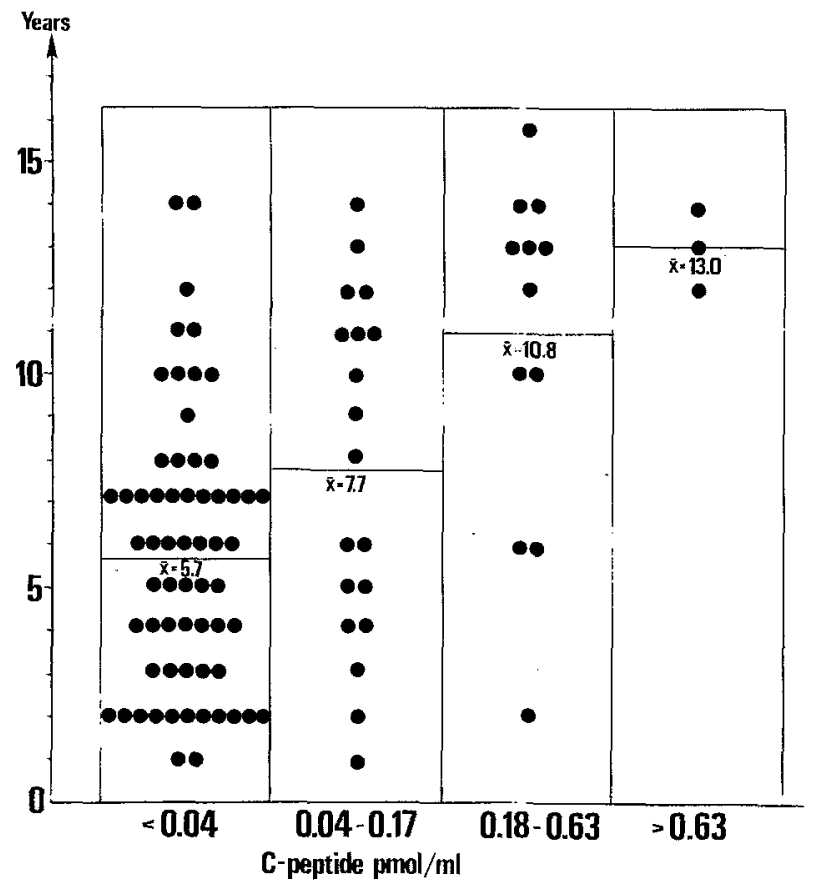

Fig. 1. C-peptide in relation to age at onset of diabetes $(\overline{\mathrm{x}}=$ mean $)$

\section{Results}

Thirty-four of the 96 children (35.4\%) had detectable amounts of serum C-peptide. Compared to nondiabetic adults studied with the same method for Cpeptide determination [8], 19 had values below, 12 within and 3 above the normal fasting range $(0.18-0.63 \mathrm{pmol} / \mathrm{ml}$ ) (Table 4). Fasting C-peptide level in non-diabetic children and adolescents comparable to the examined diabetics with regard to age, weight and sex had almost the same range $(0.22-0.73$ $\mathrm{pmol} / \mathrm{ml}$ ) [14]. Of the 34 children with detectable C-peptide, 31 had fasting hyperglycaemia ( $>5.8$ $\mathrm{mmol} / \mathrm{l})$ at the time of blood sampling, while the remaining three had blood glucose levels of $4.7,4.3$ and $4.2 \mathrm{mmol} / \mathrm{l}$. There was no significant correlation between C-peptide and fasting blood glucose (Table 5). The onset of diabetes had occurred at a later age in children with measurable C-peptide levels (Fig. 1 and Table 5) and their diabetes was of shorter duration compared with the children without C-peptide (Fig. 2 and Table 5). The number of patients who had ketonuria at the onset of the disease was similar in the patients with and those without C-peptide, but the duration of initial ketonuria was longer in those without measurable C-peptide (Table 5). Early remission periods were more frequent and of longer duration in patients with C-peptide (Table 5). High levels of insulin antibodies determined as insulin binding capacity of IgG, but also represented by the level of total IRI [10], were more often found in patients without

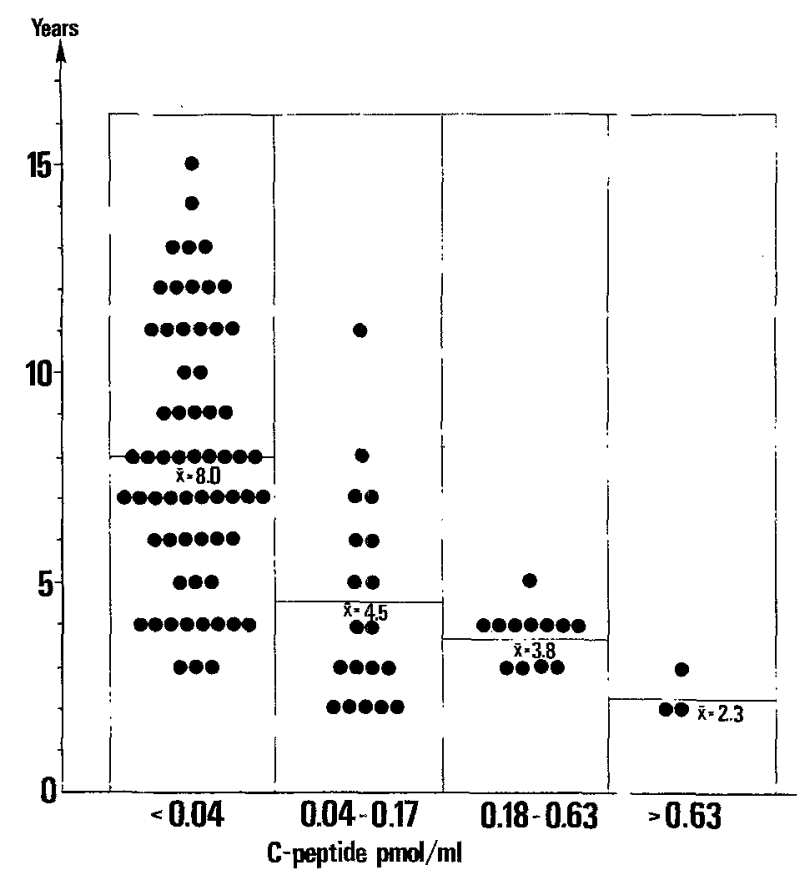

Fig. 2. C-peptide in relation to duration of diabetes $(\bar{x}=$ mcan $)$

Table 6. Relationship between C-peptide and insulin antibodies measured as IgG and IRI

\begin{tabular}{|c|c|c|c|c|c|}
\hline & \multicolumn{5}{|c|}{ C-peptide (pmol/ml) } \\
\hline & \multicolumn{2}{|c|}{$<0.04$} & \multicolumn{2}{|c|}{$\geq 0.04$} & \\
\hline & $\mathrm{n}$ & $\%$ & & $\%$ & \\
\hline \multicolumn{6}{|l|}{$\operatorname{IgG}(\mathrm{mU} / \mathrm{ml})$} \\
\hline$<0.300$ & 3 & 4.8 & 12 & 35.3 & $\mathrm{p}<0.001$ \\
\hline $0.300-2.000$ & 21 & 33.9 & 10 & 29.4 & n.s. \\
\hline \multirow[t]{2}{*}{$>2.000$} & 38 & 61.3 & 12 & 35.3 & $\mathrm{p}<0.05$ \\
\hline & 62 & 100.0 & 34 & 100.0 & \\
\hline \multicolumn{6}{|l|}{$\operatorname{IRI}(\mu \mathrm{U} / \mathrm{ml})$} \\
\hline$<300$ & 12 & 19.4 & 15 & 44.1 & $\mathrm{p}<0.01$ \\
\hline $300-1000$ & 30 & 48.4 & 11 & 32.5 & n.s. \\
\hline \multirow[t]{2}{*}{$>1000$} & 20 & 32.3 & 8 & 23.5 & n.s. \\
\hline & 62 & 100.1 & 34 & 100.1 & \\
\hline
\end{tabular}

measurable C-peptide (Table 6). This was particularly evident in the case of IgG.

\section{Discussion}

It has been assumed that insulin requiring juvenile diabetics have no residual insulin production shortly after the beginning of treatment $(5,15)$. However, the results of this study reveal that $34(35.4 \%)$ out of 96 cases of early-onset juvenile diabetes of over two years' duration, i.e. beyond the termination of any 
remission periods, showed measurable amounts of Cpeptide in their serum, which suggests that there was some residual B-cell function. The C-peptide levels in 15 patients $(15.6 \%)$ were within or above the range normal for non-diabetic adults. There are several possible explanations why these patients are insulin dependent despite the endogenous insulin production. It is possible that the fasting level of C-peptide reflects only the basal function of the B-cell. Thus these patients may be unable to release additional insulin in response to meals and glucose stimulation [17]. It is also possible that the measured C-peptide does not reflect biologically active insulin [6] or that the level of endogenous insulin production is not high enough to maintain normoglycaemia because of an elevated glucagon level [19]. In milder forms of maturity-onset diabetes there is a similar residual $\mathrm{B}$-cell function. The positive relationship found in this study between the age at onset and the level of C-peptide suggests that there is no sharp distriction between juvenile-onset and maturity onset diabetes. This is in agreement with the occurrence of chemical diabetes seen in adolescent children [4].

For the purpose of this study, remission was defined as a period devoid of or showing but a minimum of glycosuria and, hence, a period of nearly constant normoglycaemia. Patients with such remission had higher levels of C-peptide than those without. A relationship was also established between prolonged ketonuria at onset and the absence of $\mathrm{C}$-peptide later on. These differences between the groups could depend either on the severity of the disease at onset or on the type of the initial treatment. Rapid normalization of the blood sugar and ketosis may serve to preserve some B-cell function.

High levels of insulin antibodies were correlated with the absence of measurable C-peptide. This relationship may indicate a negative effect of insulin antibodies on the B-cell function, as it has been shown that insulin antibodies cause degranulation of the B-cells $[16,18]$. Human proinsulin bound to insulin antibodies has been found in insulin treated diabetics [9]. The constant depletion of insulin and proinsulin may enhance the exhaustion of the B-cells. As some insulin preparations more than others may cause the production of insulin antibodies, it seems reasonable to use insulin with as low immunogenicity as possible.

Acknowledgements. We wish to thank Miss Bente Hansen and Miss Marianne Knudsen for their excellent technical assistance. The work was supported by the Swedish Medical Research Council (Grant no B76-19X-04528-02A) and by the Medical Faculty, Linköping University, Sweden.

\section{References}

1. Beischer, W., Raptis, S., Keller, L., Heinze, E., Schröder, K. E., Pfeiffer, E. F.: Characterization of the residual beta-cell function in diabetics by a new C-peptide radioimmunoassay. Diabetologia 11, 332 (1975)

2. Block, M. B., Mako, M. E., Steiner, D. F., Rubenstein, A. H.: Circulating C-peptide immunoreactivity. Diabetes 21, 10131026 (1972)

3. Christiansen, A. H.: Radioimmunoelectrophoresis in the determination of insulin binding to IgG. Methodological studies. Horm. Metab. Res. 5, 147-154 (1973)

4. Drash, A.: Chemical diabetes mellitus in the child. Metabolism 22, 255 (1973)

5. Ehrlich, R. M.: Diabetes mellitus in childhood. Pediat. Clin. N. Amer. 21, 871-884 (1974)

6. Elliot, R. B., O'Brien, D., Roy, C. C.: An abnormal insulin in juvenile diabetes mellitus. Diabetes 14, 780-787 (1965)

7. Faber, O. K., Binder, C., Lauritzen, T., Heding, L. G.: Preserved beta-cell function and blood glucose control in insulin dependent diabetes mellitus. Abstract for Annual Meetings Program, American Diabetes Association 1976

8. Faber, O. K., Markussen, J., Naithani, V. K., Binder, C.: High titer and - sensitivity antisera to the synthetic benzyloxycarbonyl - C-peptide of human proinsulin. Hoppe-Seylers $Z$. physiol. Chem. (Acc. for publ. 1976)

9. Fink, G., Cresto, J. C., Gutman, R. A., Lavine, R. L., Rubenstein, A. H., Recant, L.: Plasma proinsulin-like material in insulin treated diabetics. Horm. Metab. Res. 6, 439-443 (1974)

10. Heding, L. G.: Determination of total serum insulin (IRI) in insulin-treated diabetic patients. Diabetologia 8, 260-266 (1972)

11. Heding, L. G.: Radioimmunological determination of human C-peptide in serum. Diabetologia 11, 541-548 (1975)

12. Heding, L. G., Munkgaard-Rasmussen, S.: Human C-peptide in normal and diabetic subjects. Diabetologia 11, 201-206 (1975)

13. Horwitz, D. L., Starr, J. I., Mako, M. E., Blackard, W. C., Rubenstein, A. H.: Proinsulin, insulin, and C-peptide concentrations in human portal and peripheral blood. J. clin. Invest. 55, 1278-1283 (1975)

14. Ludvigsson, J., Heding, L. G.: C-peptide in diabetic and nondiabetic children. Response to glucagon. (To be published)

15. Marble, A., White, P., Bradley, R. F., Krall, L. P., (eds): Joslin's diabetes mellitus. 11 ed. Philadelphia: Lea \& Febiger 1971

16. Morgan, C. R., Carpenter, A.-M., Lazarow, A.: Effect of insulin antibodies on pancreatic islet insulin and beta cell granule content. Anat. Rec. 153, 49-54 (1965)

17. Porte, D., Bagdade, J.: Human insulin secretion: an integrated approach. Ann. Rev. Med. 21, 219-240 (1970)

18. Toreson, W. E., Lee, J. C., Grodsky, G. M.: The histopathology of immune diabetes in the rabbit. Amer. J. Path. 52, 1099-1109 (1968)

19. Unger, R. H., Orci, L.: The essential role of glucagon in the pathogenesis of diabetes mellitus. Lancet 1975 I, 14-16

20. Wright, W. R., Rainwater, J. C., Tolle, L.: Glucose assay systems. Evaluation of a colorimetric hexokinase procedure. Clin. Chem. 17, 1010-1015 (1971)

Received: May 13, 1976, and in revised form: August 26, 1976

Dr. J. Ludvigsson

Dept. of Paediatrics

Univ. of Linköping

S-581 85 Linköping

Sweden 